\title{
Development and timing of two orthogonal fold systems in the western Gyeonggi Massif, Korea
}

\author{
${ }^{1}$ Department of Earth and Environmental Sciences, Korea University, Seoul 02841, Republic of Korea; *Corresponding author, E-mail: \\ haskim2@korea.ac.kr \\ ${ }^{2}$ Department of Geological Sciences, Pusan National University, Busan 46241, Republic of Korea \\ ${ }^{3}$ Division of Earth and Environmental Sciences, Korea Basic Science Institute, Cheongju, 28119, Republic of Korea
}

(Received: December 23, 2019; Revised accepted: June 11, 2020)

https://doi.org/10.18814/epiiugs/2020/020070

We present the deformation history based on analysis of two orthogonal fold phases and $U-P b$ zircon geochronology of metasedimentary and igneous rocks from the western Gyeonggi Massif (Gukhwado and Ippado areas) in the Korean Peninsula. Multiple generations of folds are recognized in three lithological units: (1) a psammitic/pelitic unit consisting of quartz-mica schist and quartzite, (2) a calcareous unit consisting of calcareous schist and calcsilicate, and (3) a mafic unit consisting of amphibolite with and without garnet porphyroblast. These rocks are intruded by a Triassic syenite. First-generation folds $\left(F_{n}\right)$ are tight to isoclinal, oriented $N-S$, and have both shallow and steep fold axes. The $F_{n}$ folds include asymmetric and buckle folds that are refolded by vertical $F_{n+1}$ folds. The latter are oriented $\sim E-W$, approximately orthogonal to the earlier folds. We infer from U-Pb zircon ages of the psammitic/ calcareous units and the syenite that the two superimposed folding phases associated with crustal-thickening and shearing in the western Gyeonggi Massif occurred between the Pennsylvanian and the Middle Triassic ( 228 Ma).

\section{Introduction}

Folds on different scales have long attracted the attention of structural geologists. They are highly variable in shape due to differences of viscosity ratio, anisotropy, and the thickness and spacing distribution of layers of different competence (Hudleston and Stephansson, 1973; Hudleston and Lan, 1992; Carreras et al., 2005; Hudleston and Treagus, 2010; Ord and Hobbs, 2013; Butler et al., 2019). Folds in layered rocks can be classified by passive and active folds based on the relation between how stress is applied and fold mechanism (Tanner, 1989; Carreras et al., 2005; Llorens et al., 2013; Ord and Hobbs, 2013). Furthermore, the active, passive, flexural folds can be formed by transpression that accommodates simultaneous shearing and shortening, and it is common in oblique convergent plate margins (Harland, 1971; Sanderson and Marchini, 1984; Fossen and Tikoff, 1993;
Woodcock and Schubert, 1994; Lin et al., 1998).

The identification of fold interference patterns provides important insights into the shortening history and kinematics associated with contractional deformation (Thiessen, 1986; Ramsay and Huber, 1987; Forbes et al., 2004). There are three generations of folds have been reported from the Anmyeondo and Yeongheungdo regions in the western Gyeonggi Massif(GM) in the Korean Peninsula, (Choi et al., 2015, 2016). The coexistence of buckle and passive folds in the study area appears to be formed by contraction with shearing that probably occurred during the late Paleozoic in response to the collision between the Sino-Korea Craton (SKC) and the South China Craton (SCC) (Fig. 1a; Oh et al., 2005, 2015; Kim et al., 2006; Cho et al., 2017a, b, 2018; Kim et al., 2018). Choi et al. $(2015,2016)$ suggested that the origin of ductile features in the western GM was associated with a combination of simultaneous shearing and shortening deformation.

The Permian-Triassic collisional orogeny affected the GM, but the exact position of this massif within the collisional belt is a matter of debate. According to some authors, the GM was part of the NE-SWstriking Hongseong-Odeasan Belt (Fig. 1) (Oh et al., 2005, 2006, 2015). Other tectonic models have attributed the western GM to the Imjingang Belt (Kim et al., 2006, 2008) or to the Gyeonggi Marginal Belt (Cho et al., 2017a, b). According to the Gyeonggi Marginal Belt model, the western GM infer one of the several sub-belts around the GM belonged to a collisional belt as like the Qinling microcontinent in China. Rocks in the western GM show evidence of multiple phases of regional metamorphism, during the Silurian-Devonian (430-400 Ma) and the Permian-Triassic (280-230 Ma), reaching upper-amphibolite-facies to high-pressure and high-temperature granulite-facies conditions (Oh et al., 2005; Kim et al., 2017b; Kim et al., 2018). However, relatively little is known about high-strain zones associated with this regional metamorphism (Kim et al., 2006; Cho et al., 2017b).

Here, we provide new structural constraints on the Permian-Triassic collisional orogeny in the western GM by recording temporal and spatial characteristics of ductile deformation in metasedimentary rocks in the areas of Gukhwado and Ippado that are located on the western margin of the Korean Peninsula (Fig. 1). The rocks in the study area show compositional layering of varied width $(2-100 \mathrm{~cm})$ and intense multiple folds. Our aims are to understand the spatial distribution of 


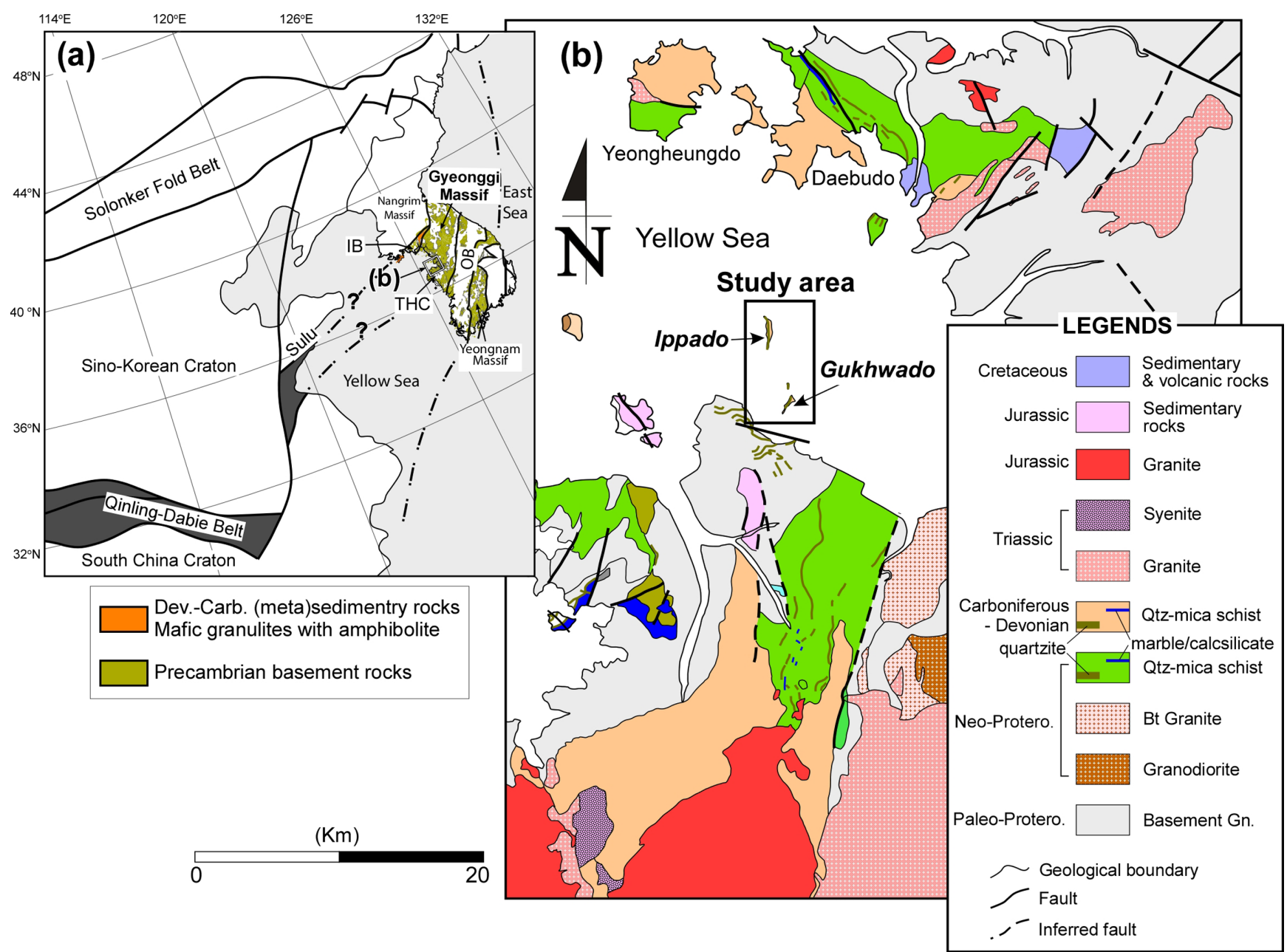

Figure 1. (a) Simplified tectonic map of the northeast Asia displays the Chinese collision Belt (Qinling-Dabie-Sulu belts) and the locations of the Precambrian Gyeonggi and Yeongnam Massifs and the Phanerozoic Imjingang and Okcheon belts in the Korean Peninsula. (b) Geological map of the study area in the western Gyeonggi massif that is part of the Taean-Hongseong Complex (THC; modified from Kim et al., 2018).

the mesoscopic folds and to constrain the timing of ductile deformation using $\mathrm{U}-\mathrm{Pb}$ zircon geochronology. On the basis of the obtained results, we discuss the deformational history of the western GM during the Permian-Triassic.

\section{Geological Setting}

The GM in the Korean Peninsula is a Precambrian basement terrane that is located between two Phanerozoic mobile belts, the Imjingang and Okcheon metamorphic belts (Fig. 1a; Chough, 2013). The GM consists mainly of quartzo-feldspathic banded and augen gneiss, migmatitic gneiss with minor quartzite, marble, calcsilicates, and amphibolite (Chough, 2013). In the western GM (Fig. 1b), major rock units include (1) Paleoproterozoic-Neoproterozoic paragneisses and orthogneisses with arc-related tonalite-trondhjemite-granodiorite suites dated at $\sim 840 \mathrm{Ma}$ (Kim et al., 2013; Park et al., 2017; Kim et al., 2018); (2) Paleozoic paragneisses (e.g., the Ordovician-Silurian Gwangcheon gneiss; Kim et al., 2017a), as well as metasedimentary rocks (Taean Formation; Cho et al., 2010); and (3) Mesozoic sedimentary and igneous rocks (Jeon et al., 2007; Seo et al., 2010; Kim et al., 2011). Silurian-Devonian and Permian-Triassic high-pressure mafic to felsic granulites and retrogressed eclogite formed at the magmatic arc and continental collisional belt, respectively, occur also in the western GM. Pressure and temperature $(\mathrm{P}-\mathrm{T})$ conditions during the Silurian-Devonian metamorphic event were 9.0-12.0 kbar and $770-870{ }^{\circ} \mathrm{C}$ (Kim et al., 2017a). During the Permian-Triassic collisional orogeny, P-T conditions were $12.0-17.0 \mathrm{kbar}$ and $800-900{ }^{\circ} \mathrm{C}$, followed by retrogressed conditions at $9.0-10.0 \mathrm{kbar}$ and $680-730^{\circ} \mathrm{C}$ (Kim et al., 2018).

Paleozoic metasedimentary rocks in the western GM consist mainly of quartz-mica schist. Prior to the discovery of middle Paleozoic ( $\sim 400$ Ma) detrital zircon grains in the Taean Formation (Cho et al., 2010), the rocks had been considered to belong to Precambrian basement (Lee et al., 1989). The youngest detrital zircon ages have been used to infer that the metasedimentary rocks in the western GM were deposited during the Carboniferous (Kim et al., 2018). On the basis of the age population of detrital zircon grains (Cho et al., 2010; Kim, 2014), it has been suggested that the western GM was part of the SCC. This proposition has major implications for the understanding of the Permian-Triassic orogeny (i.e., the Songrim orogeny) in the western part of GM. The Taean-Hongseong Complex (THC; Fig. 1; Cho et al., 2017a) is 
a branch of the Gyeonggi Marginal Belt that was intruded by Triassic and Jurassic granitoids (Kim et al., 2018). The fact that DevonianCarboniferous metasedimentary rocks in the study area (Fig. 1b) were probably formed by late Paleozoic regional deformation and metamorphism means that these rocks can be used to study the nature of the younger (Permian-Triassic) phase of orogenesis in the western GM.

Quartz-mica and calcareous schists in the study area (Gukhwado and Ippado areas) have previously been interpreted to belong to the Neoproterozoic metasedimentary basement, on the basis of the age of the youngest $\mathrm{U}-\mathrm{Pb}$ detrital zircon grains (Kim et al., 2018). However, these rocks are similar to the late Paleozoic metasedimentary rocks based on lithological and geochronological characteristics (Na et al., 2012; Han et al., 2016). The metasedimentary rocks in the western GM may have formed by various grades of metamorphism. The low grade metamorphic rocks (meta-arenite, calcareous sandstone, and mica schist; Taean Formation) occur in the Anmyeondo (Choi et al., 2008; Kim et al., 2017b). But the late Paleozoic metasedimentary rocks in the Yeo- ngheungdo and Daebudo area inferred from the maximum depositional ages using $\mathrm{U}-\mathrm{Pb}$ detrital zircon ages consist of garnet + staurolite mica schist, calcsilicate, garnet-bearing amphibolite (Na et al., 2012; Han et al., 2016) that are quite similar to those in the study area.

\section{Petrography}

Rocks in the study area belong to three units involving a metapsammitic/metapelitic unit (quartz-mica schist and quartzite), a calcareous unit (calcareous schist and calcsilicate), and a mafic unit (amphibolite) (Fig. 2a-c). The rocks are characterized by marked compositional layering that can be recognized by alternating in various thickness of the layers, although its origin is unknown so far.

The mafic layers mainly consist of amphibolite with/without garnet porphyroblast up to $5 \mathrm{~cm}$ in diameter (Fig. 2b-d). The mafic unit also occur locally as boudins within the metapsammitic/metapelitic
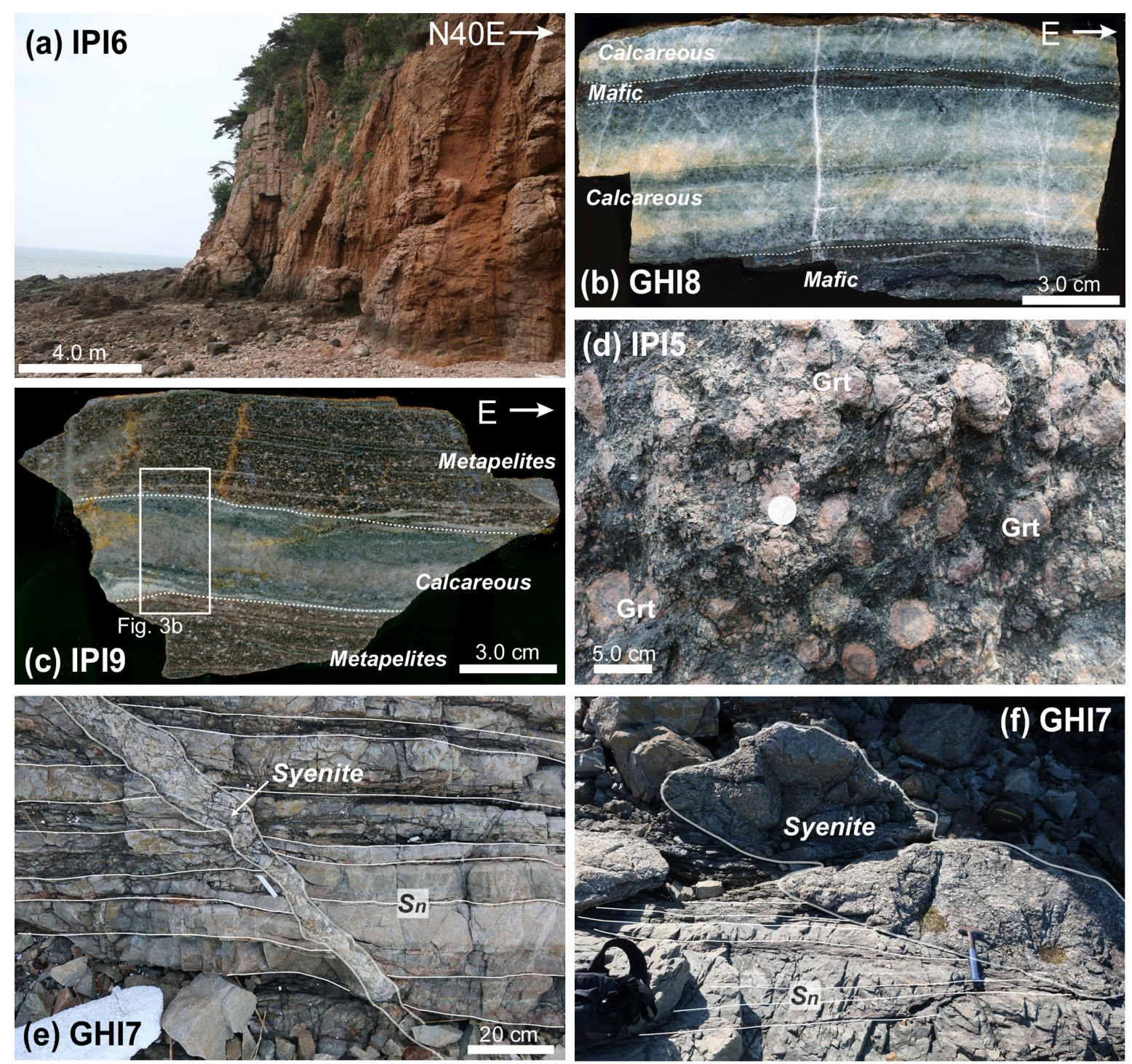

Figure 2. Outcrop and rock-slab photos showing compositional layering in the Gukhwado and Ippado. (a) Metapsammitic/metapelitic unit showing steep $S_{n}$ foliation in sample IPI6. (b) Compositional layers of calcareous and mafic units in Sample GHI8. (c) Compositional layering of metapelites and calcareous units in sample IPI9. (d) Mafic unit containing big garnet (Grt) porphyroblasts in sample IPI5. (e) and (f) Syenite crossed cut pervasive sub-vertical $S_{n}$ foliation defined by compositional layering in sample GHI7. Plane view photos. 

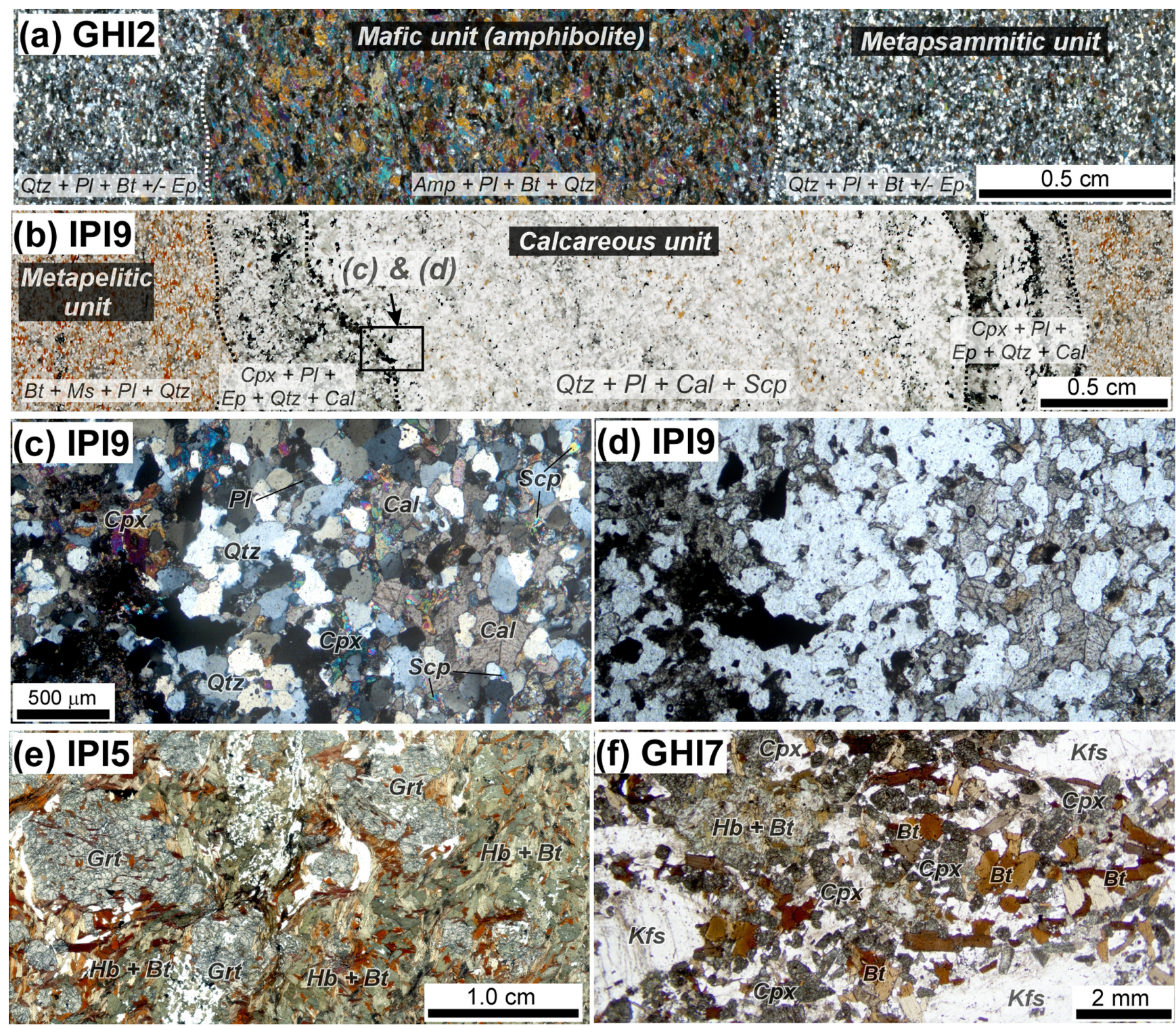

Figure 3. Photomicrographs showing mineral assemblages in three lithological units. (a) Compositional layers of mafic and metapsammitic units in sample GHI2. The mafic and metapsammitic units consist of amphibole (Amp), plagioclase (Pl), biotite (Bt) and quartz (Qtz), and Qtz, Pl and/or epidote (Ep). (b) Compositional layers of metapelite and calcareous units in sample IPI9. The metapelite consists of Bt, muscovite (Ms), Pl and Qtz, and the calcareous unit contains clinopyroxene (Cpx), calcite (Cal), Ep, Qtz with scapolite (Scp). (c) and (d) Magnified photomicrographs of box in (b) showing mineral assemblage in calcareous unit. (e) Mafic unit (amphibolite) showing Grt + hornblende (Hb) + Pl mineral assemblage with retrogressive Bt. (f) Syenite composing of Cpx, Hb, Bt with K-feldspar (Kfs) porphyry.

unit (e.g., in the Ippado area). The amphibolite consists of fine- to medium-grained amphibole, plagioclase, biotite, and quartz (Fig. 3a). These minerals are aligned parallel to the main foliation. Some of the amphibolites contain large garnet porphyroblasts with inclusions of plagioclase, amphibole, biotite, and Fe-Ti oxides (Fig. 3e).

The calcareous unit shows alternating layers with varied occurrences of calcsilicate and carbonate minerals. Abundant Ca-bearing minerals are recognized in pale- to intermediate-greenish and white layers (Fig. 2b, c). These layers alternate with white quartz- and calcite-rich layers (Fig. 2b, c). The calcareous schist contains diopside, plagioclase, amphibole, epidote, quartz, calcite, and minor scapolite (Fig. 3b). Greenish layers are characterized by a mineral assemblage of diopside, amphibole, epidote, and plagioclase. White layers consist of quartz and calcite, with scapolite occurring in some of the layers (Fig. 3c, d). Quartz-mica schist in the metapsammitic/metapelitic unit consists mainly of quartz, plagioclase, muscovite, and biotite, and minor epidote and chlorite (Fig. 3a, b). Some of the metapelitic rocks show a mineral assemblage consisting of garnet, biotite, epidote, and plagioclase. The minerals are aligned with the main foliation, which is slightly crenulated.

Cross-cutting relations are recognized between the three lithological units and a syenite intrusion (Fig. 2e, f). The latter is characterized by medium- to coarse-grained massive porphyritic texture with feldspar phenocrysts (Fig. 2e, f). The syenite consists of euhedral K-feldspar (perthite) phenocrysts, as well as clinopyroxene, hornblende, biotite, plagioclase, and quartz (Fig. 3f). 
The lithological contacts between the three units are relatively sharp (Fig. 2b, c) and lie parallel to the orientation of the mesoscopic penetrative foliation (Fig. 2e, f). The occurrence of biotite and garnet in the psammitic/pelitic unit, and diopside, scapolite, garnet, and hornblende in the calcareous and mafic units, suggests that the rocks underwent greenschist-facies to upper-amphibolite-facies metamorphism prior to the emplacement of the syenite.

\section{Deformation History}

There are two generations of foliations $\left(\mathrm{S}_{\mathrm{n}-1}\right.$ and $\left.\mathrm{S}_{\mathrm{n}}\right)$ in the Gukhwado and Ippado areas. The foliations can be recognized by compositional layering in the outcrop, and their attitude is closely related with development of multiple folding.

\section{Gukhwado Area}

The first generation of mesoscopic foliation $\left(S_{n-1}\right)$ is defined by compositional layering comprising the metapsammitic/metapelitic, calcareous, and mafic units. $\mathrm{S}_{\mathrm{n}-1}$ strikes predominantly $\mathrm{E}-\mathrm{W}$ and dips $30^{\circ}-80^{\circ}$ to the south (Fig. $4 \mathrm{a}$ ). This structural fabric is overprinted by $\mathrm{S}_{\mathrm{n}}$ that strikes NNW to WNW and dips shallowly to sub-vertically $\left(10^{\circ}-89^{\circ}\right)$ to the SSW or SW (Fig. 4a). Owing to folding, the early $S_{n-1}$ foliation is sub-parallel to the $S_{n}$ foliation in the limbs of $F_{n}$ folds. And the fold hinges of $\mathrm{F}_{\mathrm{n}}$ trend NNW-SSE to NNE-SSW with shallow and steep plunge (Fig. $4 \mathrm{~b}$ ).

First-generation mesoscopic folds $\left(F_{n}\right)$ are tight to isoclinal, and their orientations vary from recumbent to steeply inclined (Figs 5, 6). Recumbent and shallowly plunging $\left(<20^{\circ}\right) \mathrm{F}_{\mathrm{n}}$ folds (Fig. 5a, b) occur in the northern Gukhwado area and trend NNE-SSW or E-W (Fig. 4b). A top-to-the-east vergence is indicated by $F_{n}$ folds in this area (Fig. 5a, b). In the southern Gukhwado area, $F_{n}$ fold axes are steeper $\left(>45^{\circ}\right)$ and trend southward $\left(>45^{\circ} ;\right.$ Fig. $\left.5 \mathrm{c}, \mathrm{d}\right)$. The presence of asymmetric minor folds, boudins, and buckle folds around the limbs of $F_{n}$ folds (Fig. 5f, g, h) indicates that folding was accompanied by noncoaxial deformation. The sense of shear associated with asymmetric minor folds is top-to-the-north or top-to-the-south (Fig. 5f, g) that only occurs in high strain zone. However mineral or stretching lineation and shear sense indicators do not well recognize in the folded layers. The buckle folds were developed in the quartz-rich metapsammitic layers of the compositional layers, and the axes of the buckle folds (Fig. $5 \mathrm{~h}$ ) plunge shallowly $\left(<25^{\circ}\right)$ to the south.

Second-generation $\mathrm{F}_{\mathrm{n}+1}$ folds are open, and their orientations vary from inclined to vertical folds (Figs $4 \mathrm{~b}, 5 \mathrm{e}$ ). $\mathrm{F}_{\mathrm{n}+1}$ fold axes plunge steeply $\left(>45^{\circ}\right)$ towards the northeast or east (Figs $4 \mathrm{~b}, 6$ ).

\section{Ippado Area}

Mesoscopic penetrative foliation $\left(\mathrm{S}_{\mathrm{n}}\right)$ in the Ippado area is defined by compositional layering. The $\mathrm{S}_{\mathrm{n}}$ foliation strikes mainly N-S and dips steeply $\left(50^{\circ}-87^{\circ}\right)$ to the east or west (Fig. 7a). An earlier crenulated foliation $\left(\mathrm{S}_{\mathrm{n}-1}\right)$ is recognized locally (Fig. 8a), striking $\sim \mathrm{E}-\mathrm{W}$ and dipping steeply $\left(>50^{\circ}\right)$ to the south or southwest (Fig. 7a). Folding of $S_{n-1}$ and $S_{n}$ is responsible for repetitions in the compositional layering. And the fold axes of $F_{n}$ and $F_{n+1}$ are steeply plunging (Fig. 7b).

$\mathrm{F}_{\mathrm{n}}$ folds in the Ippado area are tight to isoclinal folds, and their axis orientations vary from moderately inclined to vertical folds. Minor buckle folds (Figs. 6, 8) are similar to those found in the Gukhwado area. $F_{n}$ fold axes are predominantly steeply plunging $\left(>45^{\circ}\right)$ northward (Figs. 7b, 8b, c). Various types of asymmetric fold and buckle

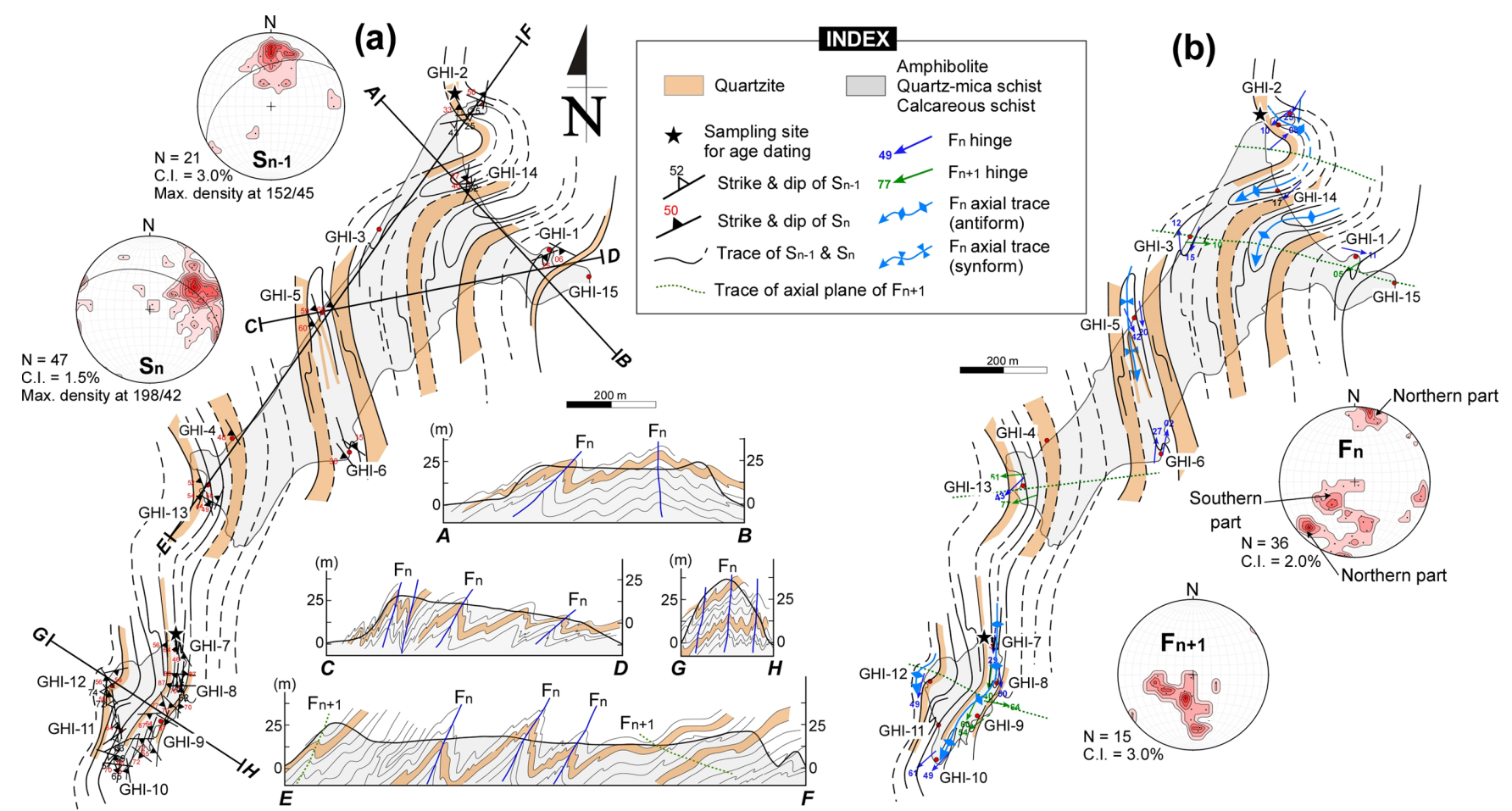

Figure 4. Geological map and cross sections of the Gukhwado. (a) A structural map showing orientation of $S_{n-1}$ and $S_{n}$ foliations with pole diagrams. (b) A structural map showing orientation of $F_{n}$ and $F_{n+1}$ folds axes with pole diagrams. 

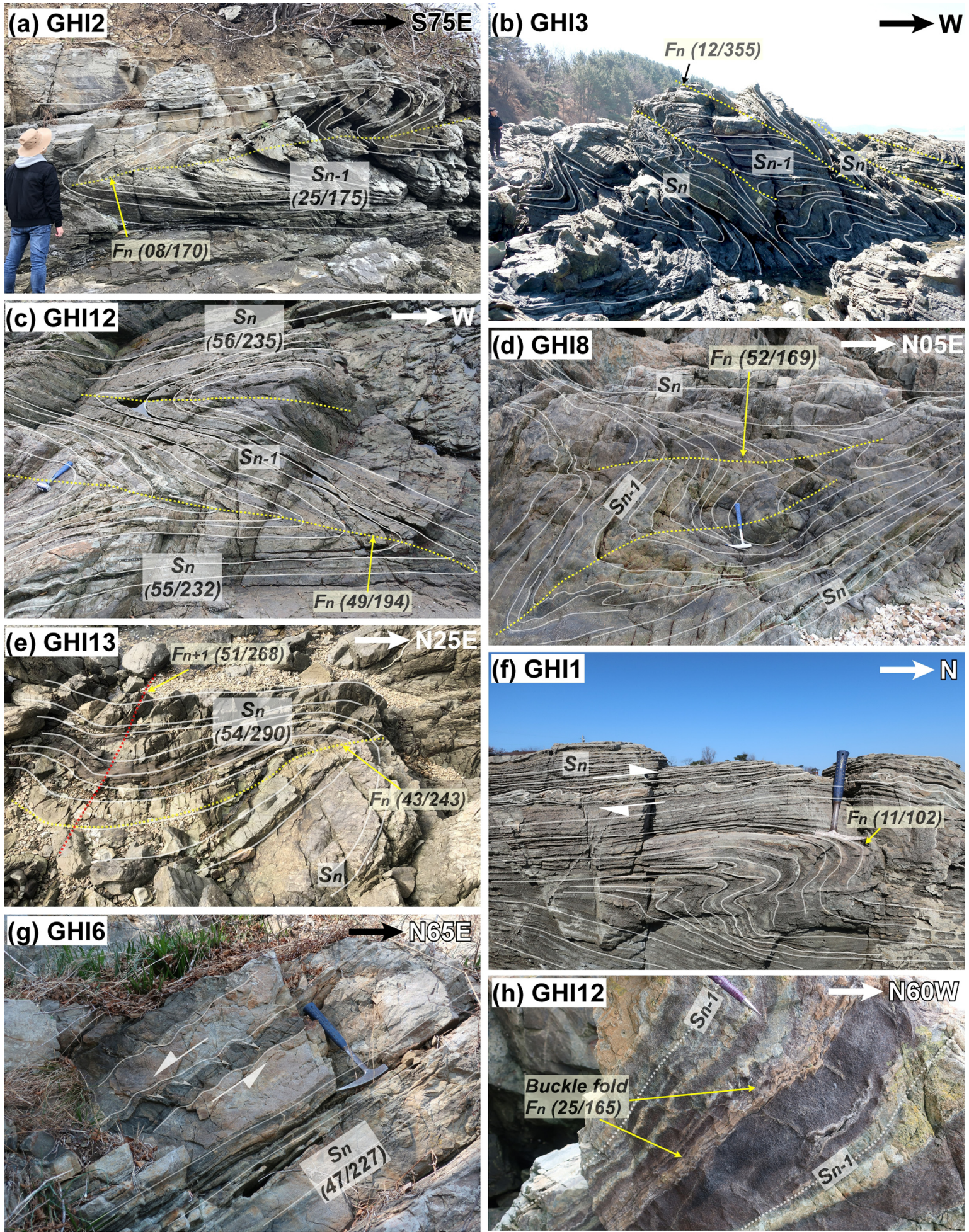

Figure 5. Outcrop photos showing various types of $F_{n}$ and $F_{n+1}$ folds in the Gukhwado. (a) Isoclinal recumbent $F_{n}$ fold. (b) Tight and shallowly inclined $F_{n}$ fold with $E$-vergence. (c) Steeply to moderately plunging inclined $F_{n}$ fold. (d) Steeply plunged inclined $F_{n}$ fold. (e) Refolded $F_{n}$ fold by E-trending $F_{n+1}$ fold. (f) Minor asymmetric $F_{n}$ fold showing $N$-vergence. (g) Asymmetric boudins of mafic unit formed by simple shearing (top-down-to-the-SW; normal sense). (h) Buckle fold of thin quartz-rich layer within the calcareous unit. Photos (c), (d) and (e) are plane-view, and the others are cross-section.

fold are recognized around the limbs of the $\mathrm{F}_{\mathrm{n}}$ folds (Fig. 8d, e). Their origin is attributed to both simple shear and pure shear. The shear sense associated with the sub-vertical $\mathrm{S}_{\mathrm{n}}$ foliation is sinistral towards the north (Fig. 8d). Buckle folds are defined by folded quartz-rich thin layers; the axes of these folds plunge $\sim 10^{\circ}$ towards the north (Fig. 8e).

Second-generation folds $\left(\mathrm{F}_{\mathrm{n}+1}\right)$ are typically vertical or steeply inclined 


\section{Dip of axial surface}

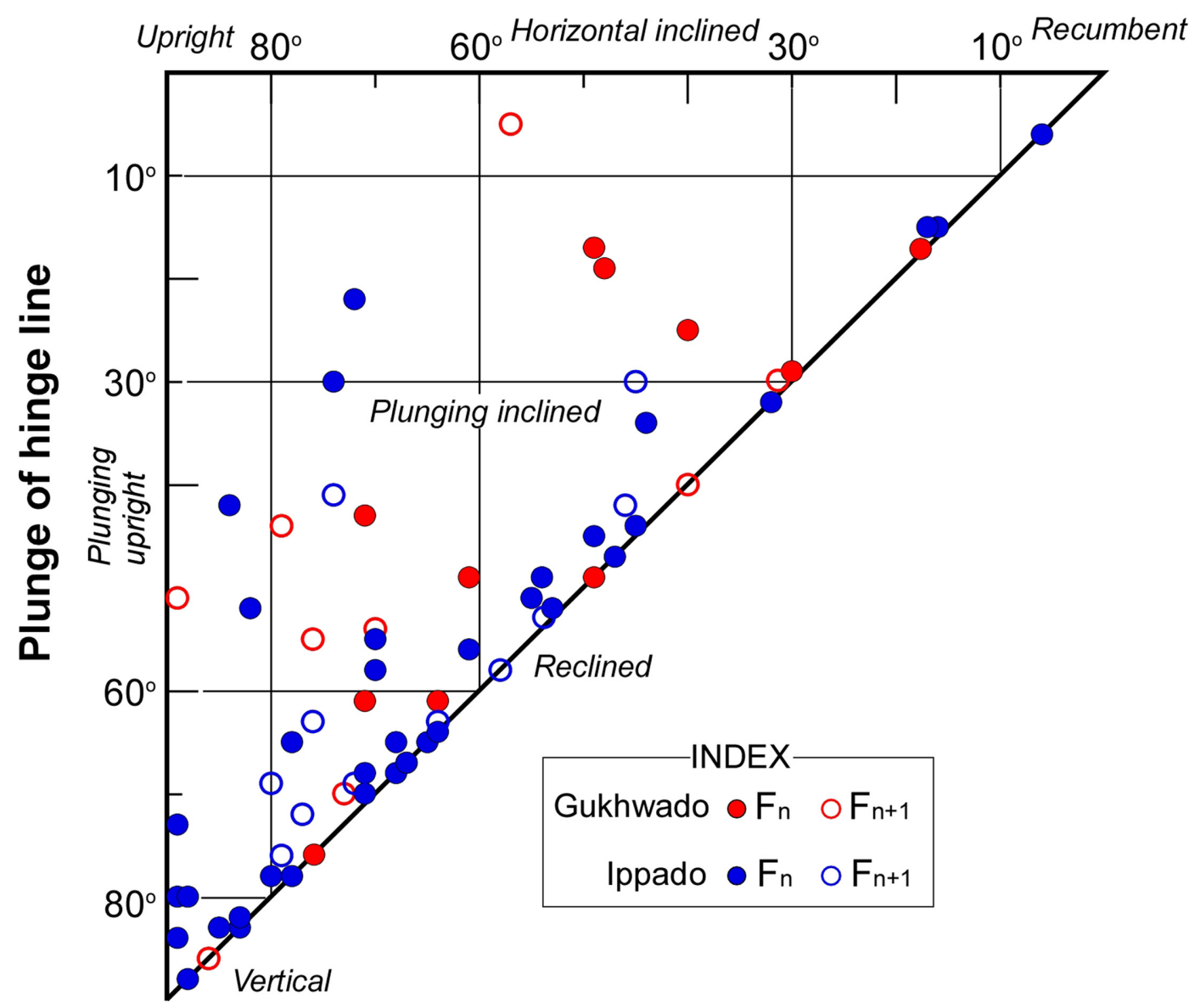

Figure 6. Classification of $F_{n}$ and $F_{n+1}$ folds in the Gukhwado and Ippado based on the orientation of the hinge line and the axial surface (Fleuty, 1964).

(Fig. 6). Their axial plane strikes ENE to WSW and dips steeply to the south (Fig. 8f). The fold axes plunge steeply $\left(>45^{\circ}\right)$ towards the NNE or SSW ( $>45^{\circ}$; Fig. $\left.7 \mathrm{~b}\right)$.

\section{U-Pb Zircon Ages}

$\mathrm{U}-\mathrm{Pb}$ isotopic analyses of zircon grains were conducted using a laser ablation-multicollector-inductively coupled plasma-mass spectrometer (LA-MC-ICPMS; Nu Plasma II/NWR193UC) and a sensitive high-resolution ion microprobe (SHRIMP IIe/MC) at the Korea Basic Science Institute, Ochang, Korea. Calibration of inter-element fractionation was performed using zircon standard 91500 (age $1065 \mathrm{Ma}$; Wiedenbeck et al., 1995). The zircon Plešovice was employed as the external standard, with a recommended weighted mean ${ }^{206} \mathrm{~Pb} /{ }^{23} \mathrm{U}$ age of 337.1 Ma (Sláma et al., 2008). Zircon standards SL13 and FC1 were also used for SHRIMP analysis. Reduction of raw data and final age calculations were conducted using the SQUID and Isoplot/Ex add-ins for Microsoft Excel, and IsoplotR (Vermeesch, 2018). U-Pb zircon data are reported in Supplementary Tables S1 and S2. Analyses with discordance of $<15 \%$ were selected for relative probability plots. ${ }^{207} \mathrm{~Pb} /{ }^{206} \mathrm{~Pb}$ ages were adopted for ages $>1000 \mathrm{Ma}$. For younger ages, we used ${ }^{206} \mathrm{~Pb} /{ }^{238} \mathrm{U}$ ages.

$\mathrm{U}-\mathrm{Pb}$ age analysis was conducted on five samples, with the aim of constraining the timing of deformation in the Gukhwado and Ippado areas. The three samples from the psammitic and calcareous schist (GHI3, GHI7, and IPI1; Table S1) contain rounded to subrounded detrital zircon grains varying from 60 to $150 \mathrm{~mm}$ in size (Fig. 9a-c). These zircons display oscillatory and banded internal zoning, which in some cases is associated with an inherited core. Some grains are mantled by a thin, bright cathodoluminescence (CL) rim. The other two samples (GHI7-1 and GHI7-2; Table S2) are from the syenite intrusion. They contain euhedral igneous zircon grains $(50-200 \mathrm{~mm}$ in size) that are characterized by strong oscillatory internal zoning (Fig. 9e).

In total, 240 of $282 \mathrm{U}-\mathrm{Pb}$ spot analyses ( $>85 \%$ ) yielded concordant results. Detrital zircon ages obtained from the psammitic and calcareous schist samples show two prominent clusters, at 1100-700 and 500-280 Ma. The samples also have subordinate Paleoproterozoic (1,900-1,600 Ma) and Neoarchean (2,400-2,700 Ma) age peaks (Figs. $9 \mathrm{a}-\mathrm{c}, 10 \mathrm{a})$. The majority of the younger concordant ages are 460-360 Ma (Ordovician-Devonian) with a few ages of 330-280 Ma (Carboniferous-Permian) (Fig. 9a-c). Th/U values of most detrital zircon grains are in the range of $0.2-4.0$, which suggests a magmatic origin (e.g., Rubatto, 2002) (Fig. 10b). However, a few younger (Carboniferous- 


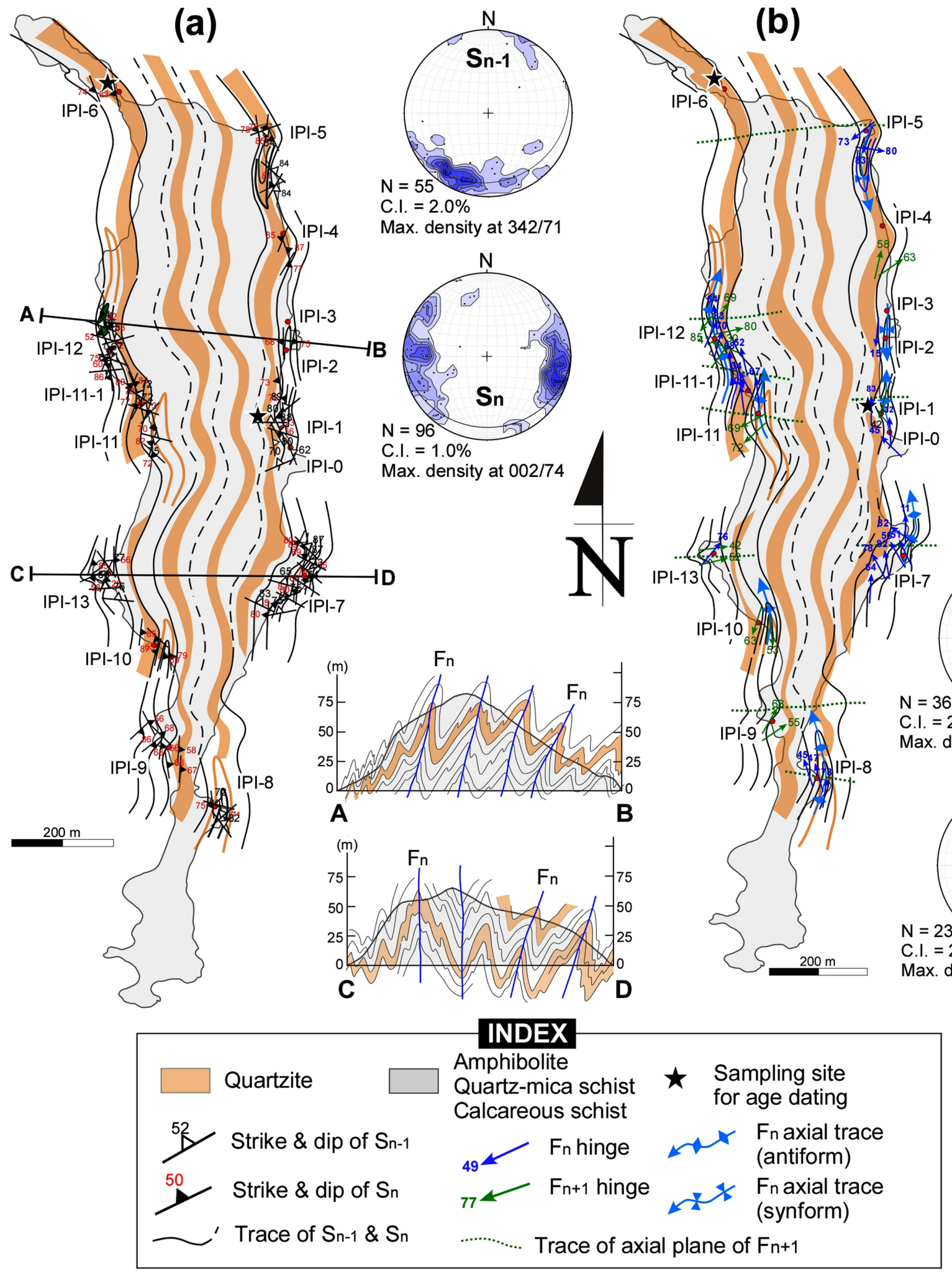

Figure 7. Geological map and cross sections of the Ippado. (a) A structural map showing orientation of $S_{n-1}$ and $S_{n}$ foliations with pole diagrams. (b) A structural map showing orientation of $F_{n}$ and $F_{n+1}$ folds axes with pole diagrams.

Permian) grains are characterized by lower $\mathrm{Th} / \mathrm{U}$ values of $<0.1$ (Fig. 10c) suggesting a metamorphic origin.

Analyses of syenite samples GHI7-1 $(\mathrm{n}=27)$ and GHI7-2 $(\mathrm{n}=28)$ yielded weighted mean ${ }^{206} \mathrm{~Pb} /{ }^{238} \mathrm{U}$ ages of $231.89 \pm 0.46(\mathrm{MSWD}=$
$0.51)$ and $231.80 \pm 0.44(\mathrm{MSWD}=0.007)$, respectively (Fig. 9d, e). These ages are interpreted as crystallization ages, thus indicating a Triassic emplacement of the syenite intrusion. 

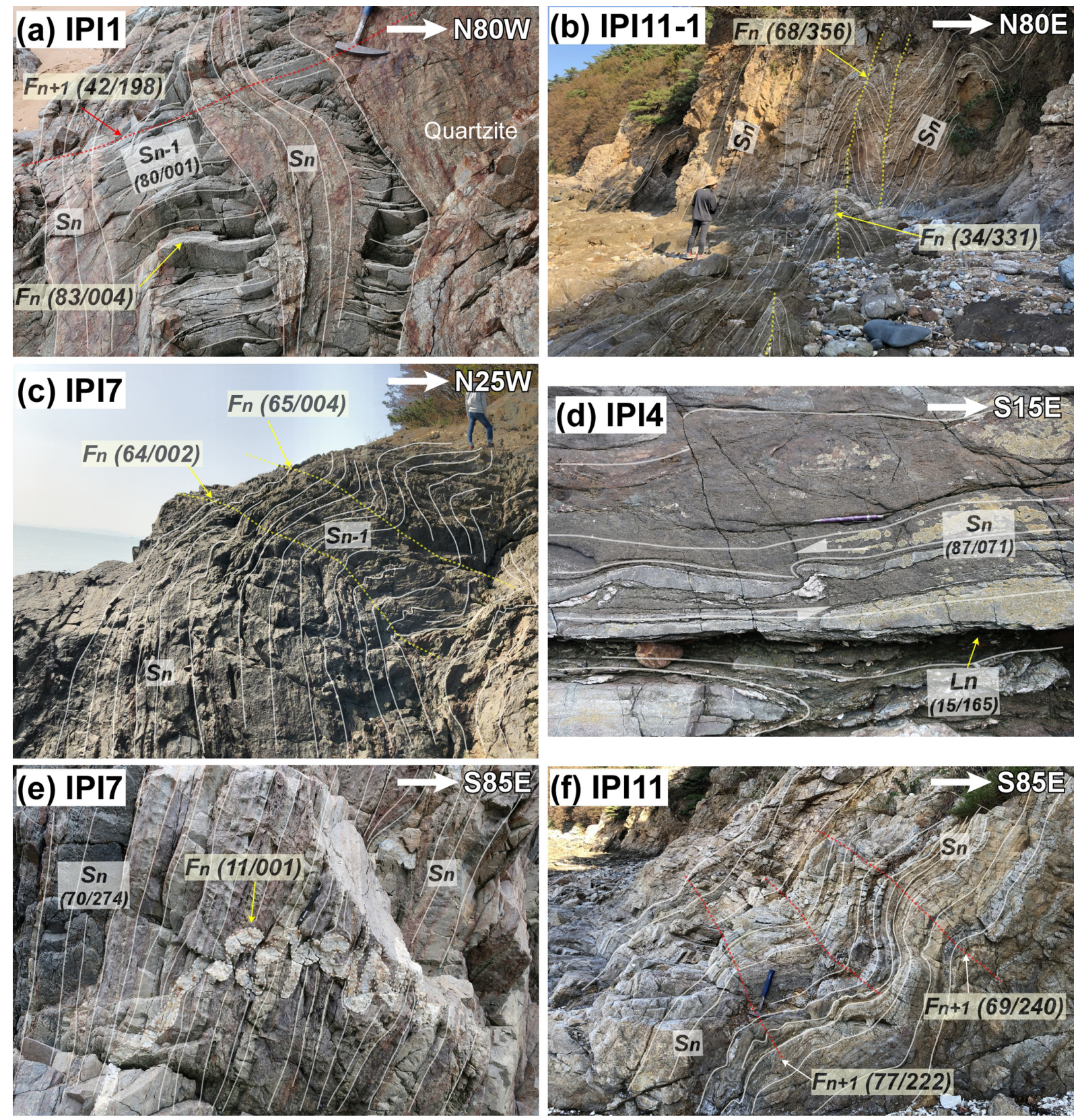

Figure 8. Outcrop photos showing various types of $F_{n}$ and $F_{n+1}$ folds in the Ippado. (a) The $F_{n}$ fold defined by steep plunging $S_{n-1}$ foliation that is truncated by $S_{n}$ foliation in quartzite. The moderately plunging $F_{n+1}$ open fold recognized by $S_{n}$. (b) Steeply plunged inclined and tight-isoclinal $F_{n}$ fold. (c) Steeply plunged inclined $F_{n}$ fold. (d) Minor asymmetric $F_{n}$ fold showing $N$-vergence. (e) Buckle fold with north trending axis. (f) Steeply plunging inclined $F_{n+1}$ fold. Photos (a) and (d) are plane-view, and the others are cross-section.

\section{Discussion}

\section{Generation of two orthogonal fold systems in the west- ern Gyeonggi Massif}

The metapsammitic/metapelitic, calcareous, and mafic units in the Gukhwado and Ippado areas were subjected to intense ductile deformation that included at least two generations of folding $\left(\mathrm{F}_{\mathrm{n}}\right.$ and $\mathrm{F}_{\mathrm{n}+1}$; Figs. 4 and 7). Structures associated with this ductile deformation include two orthogonal sets of foliations oriented $\sim \mathrm{E}-\mathrm{W}\left(\mathrm{S}_{\mathrm{n}-1}\right)$ and $\sim \mathrm{N}-\mathrm{S}\left(\mathrm{S}_{\mathrm{n}}\right)$ (Fig. 11), as well as various types of fold (Fig. 6). The earlier folds $\left(F_{n}\right)$ are tight to isoclinal and show vertical axis to recumbent, and their fold axes plunge shallowly to steeply to the N-S or EW (Fig. 11). They also show buckle folds (Figs. 5 and 8). $F_{n+1}$ fold axes are typically steeply plunging to vertical (Fig. 11).

Contractional deformation is inferred to have been initiated with the formation of an asymmetric monocline and open folding of the $S_{n-1}$ foliation. The origin of $S_{n-1}$ is ambiguous because it is difficult to constrain the characteristics and timing of regional metamorphism that formed compositional layering in the study area. With continued contractional deformation, the $S_{n-1}$ foliation was transposed into the verti- 

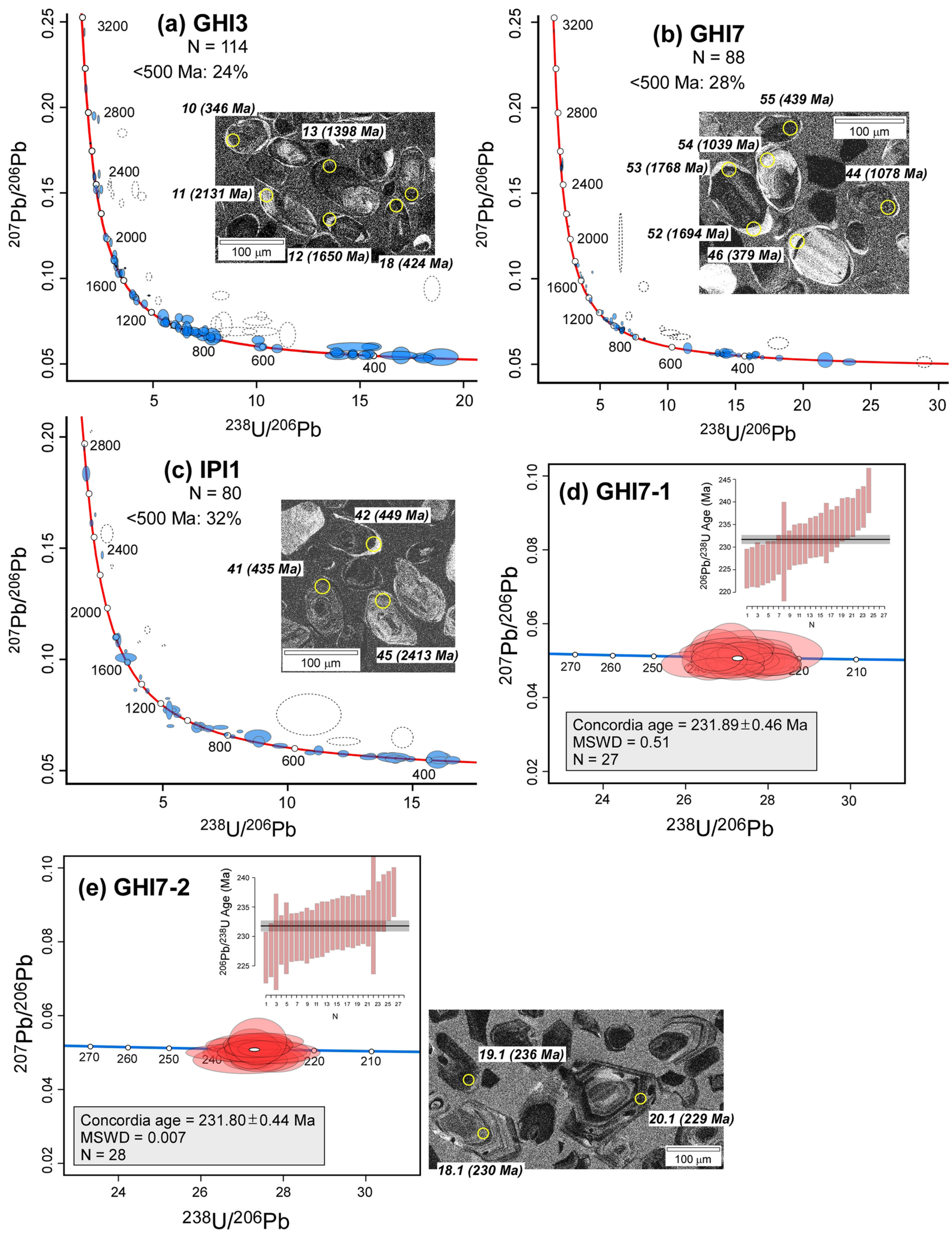

Figure 9. (a)-(c) Terra-Wasserburg concordia diagrams with CL images for the U-Pb detrital zircon data from metapsammitic (IPII) and calcareous units (samples GHI2 and GHI7) in the Gukhwado and Ippado. (d) and (e) Terra-Wasserburg diagrams with CL image showing the SHRIMP U-Pb zircon ages combined with a weighted mean ${ }^{206} \mathrm{~Pb}{ }^{238} \mathrm{U}$ age of syenite in the Gukhwado. Numbers in the CL images represent spot number and ages. 
(a)

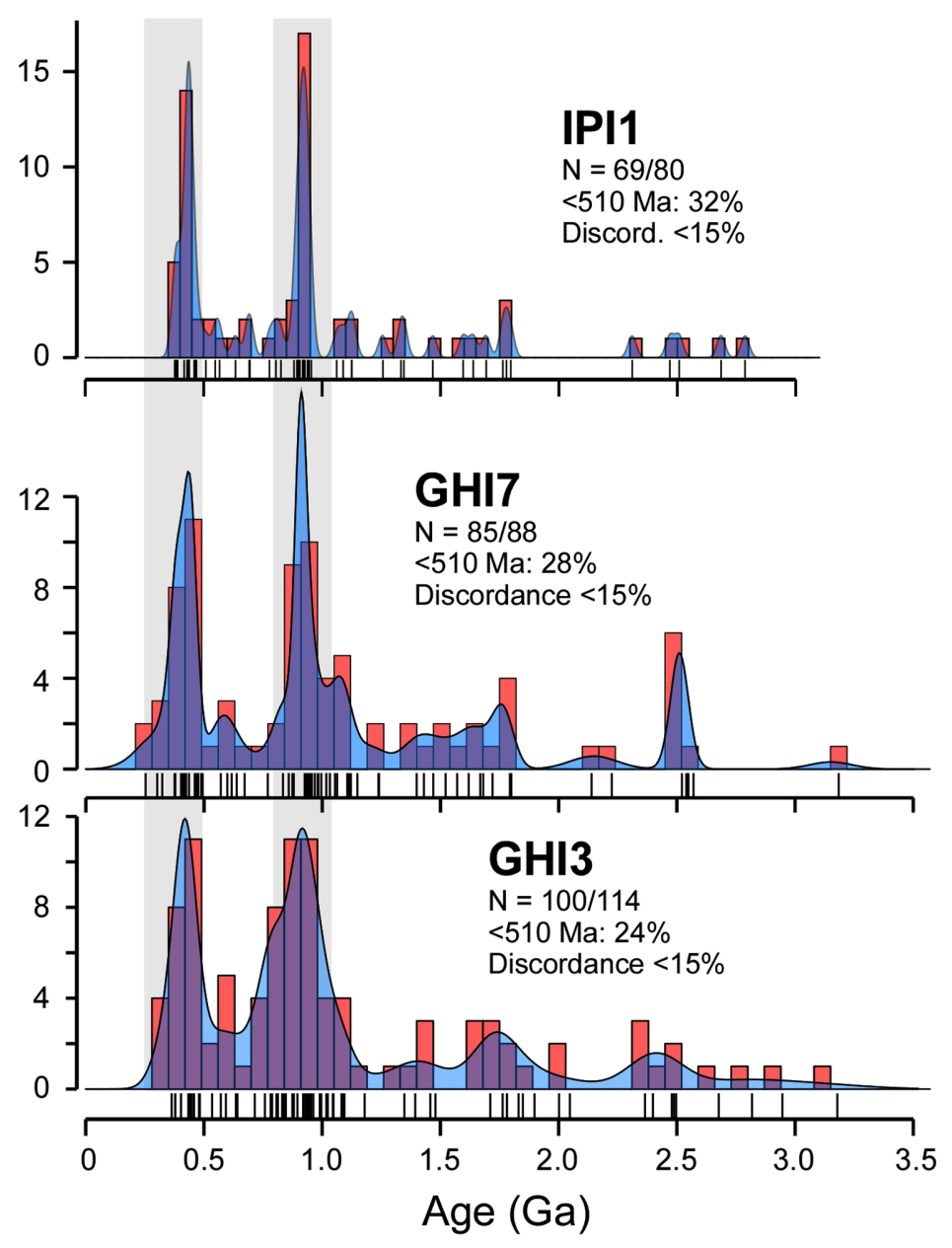

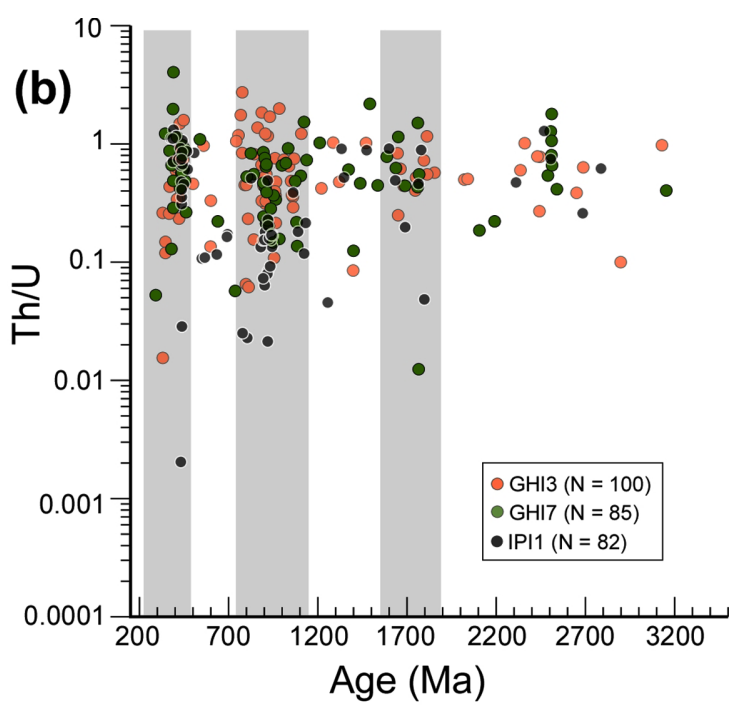

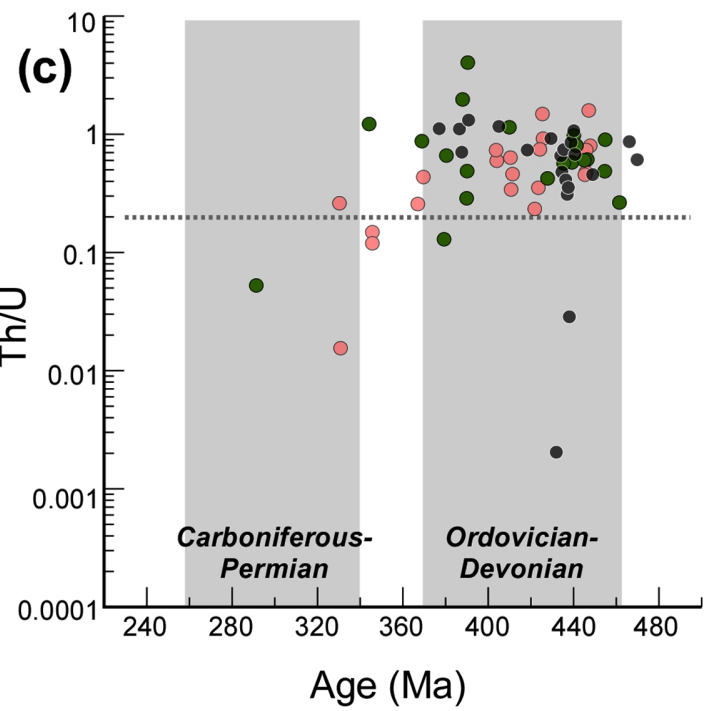

Figure 10. (a) Relative probability diagram with kernel densities (KDE; Vermeesch, 2018) of detrital zircon ages of the late Paleozoic metamorphic rocks in the Gukhwado and Ippado, western GM. (b) Concordant age versus Th/U ratio diagram for three samples (GHI4, 7 and IPI1). (c) $\mathrm{Th} / \mathrm{U}$ ratio variation of the younger ages $(<480 \mathrm{Ma})$.

cal orientation of $S_{n}$. The monoclines tightened into asymmetric folds, and their axial surfaces became sub-vertical. Buckle fold belonging to $\mathrm{F}_{\mathrm{n}}$ folds, which have sub-horizontal north and south-trending axes (Figs $5 \mathrm{~h}$ and $8 \mathrm{e}$ ), might be generated by sub-horizontal E-W shortening if the buck folds, mainly resulted from pure shear. However, the single layer buckle folds can be also formed by simple shear (Llorens et al., 2013). As strain accumulated, lithological boundaries are subparallel to $S_{n}$ (Figs. 5b, d, and $8 b$ ). The geometry of $F_{n}$ folds is complicated because these earlier structures were refolded by inclined and subvertical $F_{n+1}$ folds. In the hinge areas of $F_{n+1}$ folds, $F_{n}$ fold axes were rotated, thus producing shallowly inclined folds (Fig. 5e, 8a, and f).

A similar style of two superimposed folding phases has been reported from the southern THC, in the area of Anmyeondo (Choi et al., 2015). The Taean Formation in this area was regionally affected by an earlier event of tight to isoclinal folding and a later folding event that produced E-W-trending vertical folds (Choi et al., 2015). Choi et al. (2015) have further suggested that the development of mylonitic foliations sub-parallel to the axial plane of isoclinal folds resulted from a combination of shortening and minor oblique dextral shearing (top-to-the-NNE). Therefore, the two orthogonal fold system in the study area was probably linked to the major phase of crustal thickening in the in the western GM during the late Paleozoic. However, further studies based on additional kinematic indicators in microscopic scale, considering different compositional layers, will enhance more reliable deformation model. This will also serve to elucidate the previously uncertain the Permian-Triassic collisional orogeny affected the western GM.

\section{Timing of Deformation and Implications for Late Paleo- zoic Orogenesis}

Our new zircon ages from the metapsammitic and calcareous units and from the syenite intrusion can be used to constrain the timing of ductile deformation in the western GM, which has hitherto been poorly constrained. The new U-Pb zircon ages indicate that two superimposed folding phases occurred after deposition of the sedimentary 


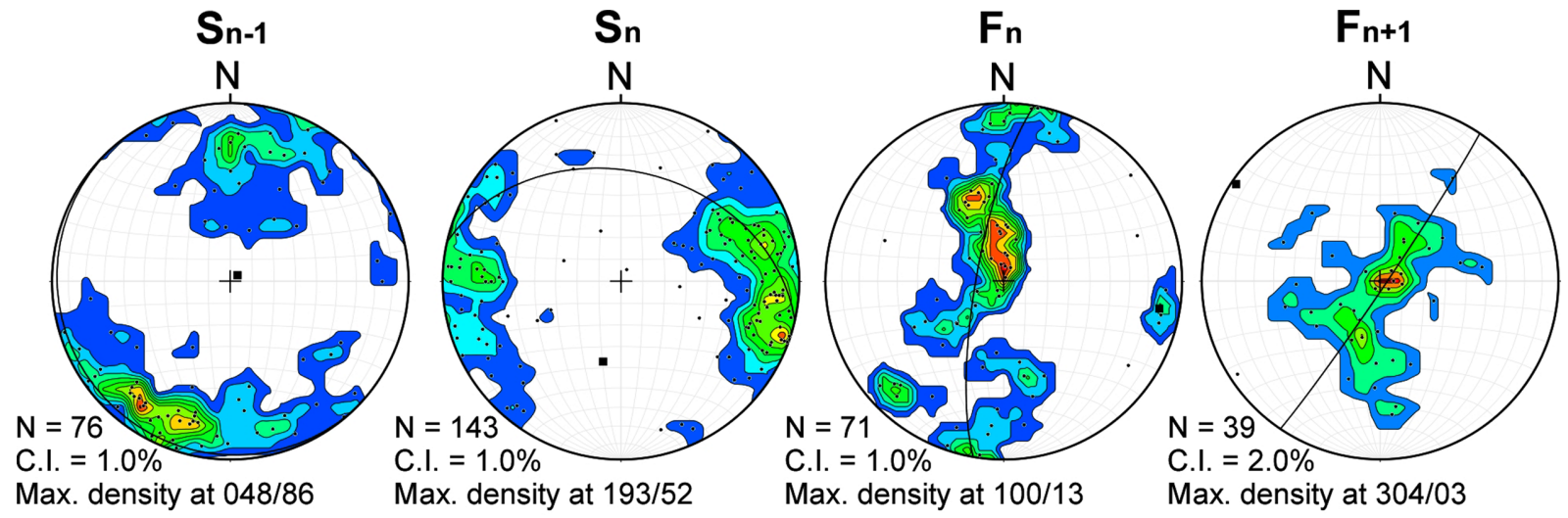

Figure 11. Pole diagrams displaying orientation of all $S_{n-1}$ and $S_{n}$ foliations plus axes of $F_{n}$ and $F_{n+1}$ in the Gukhwado and Ippado.

protoliths and prior to emplacement of the syenite ( $\sim 232 \mathrm{Ma})$.

Detrital age spectra in samples GHI1, GHI2, and IPI1 display two dominant peaks at 1000-700 Ma (Neoproterozoic) and 500-320 Ma (early-middle Paleozoic) including the late Carboniferous to early Permian ages (330-280 Ma; Fig. 10). Similar detrital zircon age clusters have been found in Paleozoic metasedimentary rocks from the THC (Fig. 12; Cho et al., 2010; Na et al., 2012; Kim et al., 2014). A comparison of age spectra using a Kolmogorov-Smirnov (K-S) test and R statistical software (v. 3.2.3; Marsaglia et al., 2003; Hornik, 2015 ) shows that the probabilities ( $p$ values) of the K-S test are mostly $>0.05$ (Fig. 12). We therefore suggest that the metasedimentary rocks in our study area and the metasedimentary rocks in Yeongheungdo (Na et al., 2012), the Taean Formation (Cho et al., 2010), Anmyeon- ndo, and Daebudo (Kim et al., 2014) might have been derived from source rocks with similar ages. Cho (2007) and Cho et al. (2010) suggested that that the depositional age of the Taean Formation is 430 $420 \mathrm{Ma}$ and ca. 402-229 Ma, respectively, based on SHRIMP U-Pb ages of detrital zircon and the Triassic intrusion ages. Kim et al (2017b) also documented that the youngest detrital zircon ages of ca. 440-424 $\mathrm{Ma}$, zircon overgrowth ages of ca. 277-260 Ma and metamorphic ages of ca. 243-234 Ma based on SHRIMP U-Pb ages of detrital and inherited zircon grains and LA-MC-ICPMS U-Pb ages of zircon overgrowth and SHRIMP U-Pb ages of titanite, respectively. And they interpreted that a possible maximum depositional age of the Taean Formation in the Anmyeondo is 277-260 Ma. But it appears to be ambiguous because the ages can represent metamorphic event after

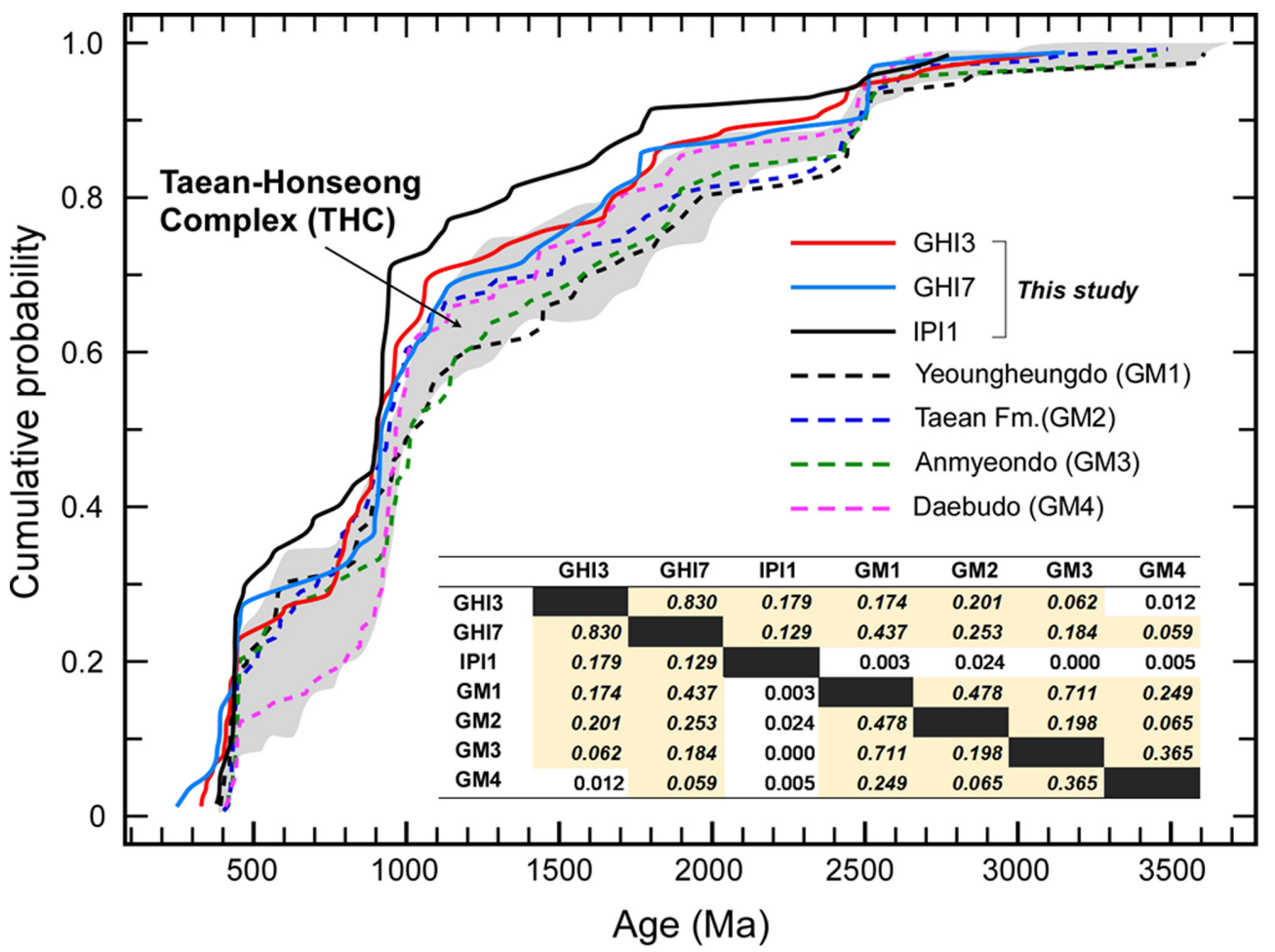

Figure 12. Cumulative age probability diagram of the detrital zircon from the metapsammitic and calcareous units in the Gukhwado and Ippado, and the Carboniferous-Devonian metasedimentary rocks in the Yeongheungdo (Na et al., 2012), Taean Formation (Cho et al., 2010), Anmyeondo and Daebudo (Kim et al., 2014). Insert table shows Kolmogorov-Smirnov (K-S) p values for all samples in the Taean-Hongseong Complex. $P$ values larger than 0.05 are in bold text with shade. 
deposition of the Taean Formation. Therefore, the lower limit for the timing of two superimposed folding phases in the study area is ca. 402-330 Ma.

The upper limit for the timing of deformation can be determined by the Triassic ages of syenite and granite intrusions in the western GM. A zone of Triassic syenites occurs in the western part of the study area (Choi et al., 2015), showing a general $\sim \mathrm{N}-\mathrm{S}$ trend that is sub-parallel to the Paleozoic metasedimentary rocks. A syenite intrusion from the southern part of the area shown in Fig. $1 \mathrm{~b}$ has been dated at $220.3 \pm$ 4.0 Ma (Kim et al., 2018). Triassic granites from the southern and northern parts of the area shown in Fig. $1 \mathrm{~b}$ are characterized by two different textures. The first type is a massive, coarse- to fine-grained biotite granite, which has been dated at 229-227 Ma by U-Pb zircon geochronology (Kim et al., 2018). The second type is a strongly foliated biotite granite, for which the timings of emplacement and deformation were constrained at $\sim 242 \mathrm{Ma}$ and $\sim 228 \mathrm{Ma}$, respectively (Kim et al., 2018). This information, together with our new constraint on the timing of the syenite emplacement $(\sim 232 \mathrm{Ma})$, implies $\sim 228 \mathrm{Ma}$ as an upper age limit for the timing of two generations of fold phases. Consequently, we interpret that $F_{n}$ and $F_{n+1}$ folding in the western GM took place during the Pennsylvanian - the Middle Triassic. One of attractive candidate for the deformation timing is Guadalupian (ca. $280 \mathrm{Ma}$ ) to Camian (ca. $230 \mathrm{Ma}$ ) based on titanite SHRIMP U-Pb and muscovite ${ }^{40} \mathrm{Ar}{ }^{\beta 9} \mathrm{Ar}$ ages from the Taean Formation (De Jong et al., 2014, 2015; Kim et al., 2017b) indicating regional metamorphic and deformation ages. Further research on the tectonometamorphic evolution of the Permian-Triassic orogeny will require an understanding of the spatial and temporal relationships between the multiple folding events, activity along thrusts and shear zones, and peak metamorphic conditions of the different lithological units in the western GM.

\section{Conclusions}

This study documents the two superimposed folding phases that are recognized in compositional layers composing of psammitic/pelitic, calcareous, and mafic units in the western Gyeonggi Massif, Korea. Penetrative $S_{n-1}$ and $S_{n}$ foliations record two phases of ductile deformation. The earlier deformation was associated with the development of NNW- to NNE-trending folds $\left(F_{n}\right)$. The second phase of deformation produced $\mathrm{E}-\mathrm{W}$-trending steeply plunging and vertical folds $\left(\mathrm{F}_{\mathrm{n}+1}\right)$, which refolded the earlier structures. The diversity of fold types likely resulted from contractional deformation with shearing. On the basis of $\mathrm{U}-\mathrm{Pb}$ zircon ages from the psammitic and calcareous units and from the intruded syenite, we determine that two superimposed folding phases were associated with the Permian the Middle Triassic ( $\sim 228 \mathrm{Ma}$ ) orogenic processes. Multiple generations of fold structures in the western GM were probably generated by crustal thickening associated with this orogeny.

\section{Acknowledgments}

This study is supported by the Basic Science Research Program through the National Research Foundation of Korea (NRF) funded by the Ministry of Science and ICT 2017R1D1A1B04028521 to H. S.
Kim. We thank Dr. Daniel Pastor-Galán and an anonymous reviewer for helpful and constructive suggestions that improved the manuscript significantly.

\section{References}

Butler, R.W.H., Bond, C.E., Cooper, M.A., and Watkins, H., 2019, Foldthrust structures - where have all the buckles gone? In C.E. Bond \& H.D. Lebit, (Eds), Folding and Fracturing of Rocks: 50 Years of Research since the Seminal Text Book of J. G. Ramsay. Geological Society, London, Special Publications, v. 487, pp. 21-44.

Carreras, J., Druguet, E., and Griera, A., 2005, Shear zone-related folds. Journal of Structural Geology, v. 27, pp. 1229-1251.

Cho, D.L., 2007. SHRIMP zircon dating of a low-grade meta-sandstone from the Taean Formation: provenance and its tectonic implications. Korea institute of Geoscience and mineral resources Bulletin, v. 11, pp. $3-14$.

Cho, M, Lee, Y, Kim, T, Cheong, W, Kim, Y, and Lee, S.R., 2017b, Tectonic evolution of Precambrian basement massifs and an adjoining fold-and-thrust belt (Gyeonggi Marginal Belt), Korea: An overview. Geosciences Journal, v. 21, pp. 845-865.

Cho, M., Kim, T., Yang, S-Y., and Yi, K., 2017a, Paleoproterozoic to Triassic crustal evolution of the Gyeonggi Massif, Korea: Tectonic correlation with the North China craton. In R. D. Law, J. R. Thigpen, A. J. Merschat, \& H. Stowell, (Eds), Linkages and feedbacks in orogenic systems. Geological Society of America Memoir 213, pp. 165-197.

Cho, M., Min, K., and Kim, H., 2018, Geology of the 2018 Winter Olympic site, Pyeongchang, Korea. International Geology Review, v. 60, pp. 267-287.

Cho, M., Na, J., and Yi, K., 2010, SHRIMP U-Pb ages of detrital zircons in metasandstones of the Taean Formation, western Gyeonggi massif, Korea: tectonic implications. Geosciences Journal, v. 14, pp. 99-109.

Choi, P.-Y., Kihm, Y.H., and Chun, H.Y., 2016, Geological report of the Yeongheungdo, Pungdo, Gyeongnyeolbiyeoldo, Gungsido, Geodo and Naepasudo sheet $(1: 50,000)$. Korea Institute of Geoscience and Mineral Resources, $54 \mathrm{p}$.

Choi, P.-Y., Kihm, Y.H., Chun, H.Y., and Hwang, J.H., 2015, Geological report of the Anmyeondo, Wonsando, Hwangdo, Oeyeondom Hodo sheets $(1: 50,000)$. Korea Institute of Geoscience and Mineral Resources, $80 \mathrm{p}$.

Chough, S.K., 2013, Geology and Sedimentology of Korean Peninsula. Elsevier Insights, Elsevier, $363 \mathrm{p}$.

de Jong, K., Han, S., Ruffet, G., Yi, K., 2014. First age constraints on the timing of metamorphism of the Taean Formation, Anmyeondo: concordant $233 \mathrm{Ma} \mathrm{U}-\mathrm{Pb}$ titanite and $231-229 \mathrm{Ma}^{40} \mathrm{Ar} /{ }^{\beta 9} \mathrm{Ar}$ muscovite ages. Journal of Geological Society of Korea, v. 50, pp. 593-609.

de Jong, K., Han, S., and Ruffet, G., 2015, Fast cooling following a Late Triassic metamorphic and magmatic pulse: Implications for the tectonic evolution of the Korean collision belt. Tectonophysics, v. 662, pp. 271-290.

Fleuty, M.J., 1964, The description of folds. London: Proceedings of the Geologist' Association, v. 75, pp. 461-492.

Forbes, C.J., Betts, P.G., and Lister, G.S., 2004, Synchronous development of Type 2 and Type 3 fold interference patterns: evidence for recumbent sheath folds in the Allendale Area, Broken Hill, NSW, Australia. Journal of Structural Geology, v. 26, pp. 113-126.

Fossen, H., and Tikoff, B., 1993, The deformation matrix for simultaneous simple shearing, pure shearing and volume change, and its application to transpression-transtension tectonics. Journal of Structural Geology, v. 15, pp. 413-422.

Harland, W. B., 1971, Tectonic transpression in Caledonian Spitsbergen. Geological Magazine v. 108, pp. 27-42.

Hornik, K., 2015, Frequently asked questions on R. https://CRAN.R-project.org/doc/FAQ/RFAQ.html. 
Hudleston, P.J., and Stephansson, O., 1973, Layer shortening and foldshape development in the buckling of single layers. Tectonophysics, v. 17, pp. 299-321.

Hudleston, P.J., and Lan, L., 1992, Information from fold shapes. Journal of Structural Geology, v. 15, pp. 253-264.

Hudleston, P.J., and Treagus, S.H., 2010, Information from folds: A review. Journal of Structural Geology, v. 32, pp. 2042-2071.

Jeon, H., Cho, M., Kim, H., Horie, K., and Hidaka, H., 2007, Early Archean to Middle Jurassic evolution of the Korean Peninsula and its correlation with Chinese cratons: SHRIMP U-Pb zircon age constraints. Journal of Geology, v. 115, pp.525-539.

Kim, H., Song, K.Y., Kwon, C.W., Lee, Y., and Choi, S.-J., 2018, 1:100,000 Tectonostratigraphic map of the Dangjin-Deasan area. Korea Institute of Geoscience and Mineral Resources.

Kim, H.S., Kwon, S., Kim, S.W., and Santosh, M., 2018, Permo-Triassic high-pressure metamorphism in the central western Korean Peninsula, and its link to Paleo-Tethyan Ocean closure: key issues revisited. Geoscience Fontiers, v. 9, pp. 1325-1335.

Kim, S.-W., Kwon, S., Koh, H.J., Yi, K., Jeong, Y.-J., and Santosh, M., 2011, Geotectonic framework of Permo-Triassic magmatism within the Korean Peninsula. Gondwana Research, v. 20, pp. 865-889.

Kim, S.W., Kee, W.-S., Lee, S.R., Santosh, M., and Kwon, S., 2013, Neoproterozoic plutonic rocks from the western Gyeonggi massif, South Korea: Implications for the amalgamation and break-up of the Rodinia supercontinent: Precambrian Research, v. 227, pp. 349-367.

Kim, S.W., Kwon, S., Park, S.I., Yi, K., Santosh, M., and Kim, H.S., 2017a, Early to Middle Paleozoic tectonometamorphic evolution of the Hongseong area, central western Korean Peninsula: Tectonic implications. Gondwana Research, v. 47, pp. 308-322.

Kim, S.W., Kwon, S., Santosh, M., Cho, D.L., and Ryu, I.-C., 2014, Detrital zircon U-Pb geochronology and tectonic implications of the Paleozoic sequences in western South Korea. Journal of Asian Earth Sciences, v. 95, pp. 217-227.

Kim, S.W., Oh, C.W., Williams, I.S., Rubatto, D., Ryu, I.-C., Rajesh, V.J., Kim, C.-B., Guo, J., and Zhai., M., 2006, Phanerozoic high-pressure eclogite and intermediate-pressure granulite facies metamorphism in the Gyeonggi Massif, South Korea: Implications for the eastward extension of the Dabie-Sulu continental collision zone: Lithos, v. 92, pp. 357-377.

Kim, S.W., Park, S.-I., Jang, Y., Kown, S., Kim, S.J., and Santosh, M., 2017b, Tracking Paleozoic evolution of the South Korean Peninsula from detrital zircon records: Implications for the tectonic history of East Asia. Gondwana Research, v. 50, pp. 195-215.

Kim, S.W., Williams, I.S., Kwon, S., and Oh, C.W., 2008, SHRIMP zircon geochronology, and geochemical characteristics of metaplutonic rocks from the southwestern Gyeonggi block, Korea: Implications for Paleoproterozoic to Mesozoic tectonic links between the Korean Peninsula and eastern China. Precambrian Research, v. 162, pp. 475-497.

Kim, Y., Aum, H.W., Cheong, W., Kim, T., and Yi, K., 2014, An occurrence of the post-orogenic Triassic strata on Deokjeok Island, western Gyeonggi massif, Korea. Geosciences Journal, v. 18, pp. 137-147.

Lee, S.M., Kim, H.S., Na, K.C., and Park, B.Y., 1989, Geological report of the Dangjin, Changgohang sheet (1:50000). Korea Institute of Energy and Resources, $15 \mathrm{p}$.

Lin, S., Jiang, D., Williams, P.F., 1998, Transpression (or transtension) zones of triclinic symmetry natural example and theoretical modelling. Geological Society of London Special Publications, v. 135, pp. 41-57.
Llorens, M.-G., Bons, P.D., Griera, A., Gomez-Rivas, E., and Evans, L.A., 2013, Single layer folding in simple shear. Journal of Structural Geology, v. 50, pp. 209-220.

Marsaglia, G., Tsang, W.W., and Wang, J., 2003, Evaluating Kolmogorov's distribution. Journal of Statistical Software, v. 8, pp. 1-4.

Na, J., Kim, Y., Cho, M., and Yi, K., 2012, SHRIMP U-Pb Ages of Detrital Zircons from Metasedimentary Rocks in the Yeongheung-SeonjaeDaebu Islands, Northwestern Gyeonggi Massif. Journal of Petrological Society of Korea, v. 21, pp. 31-45.

Oh, C.W., Imayama, T., Lee, S.Y., Yi, S.B., Yi, K., and Lee, B.C., 2015, Permo-Triassic and Paleoproterozoic metamorphism related to continental collision in Yangpyeong, South Korea. Lithos, v. 216-217, pp. 264-284.

Oh, C.W., Kim, S.W., and Williams, I.S., 2006, Spinel granulite in Odesan area, South Korea: Tectonic implications for the collision between the North and South China blocks. Lithos, v. 92, pp. 557-575.

Oh, C.W., Kim, S.W., Choi, S.G., Zhai, M., Guo, J., and Sajeev, K., 2005, First finding of eclogite facies metamorphic event in South Korea and its correlation with the Dabie-Sulu collision belt in China. Journal of Geology, v. 113, pp. 226-232.

Ord, A., and Hobbs, B., 2013, Localised folding in general deformations. Tectonophysics, v. 587, pp. 30-45.

Park, S.-I., Kim, S.W., Kwon, S., Santosh, M., Ko, K., and Kee, W.-S., 2017, Nature of Late Mesoproterozoic to Early Neoproterozoic magmatism in the western Gyeonggi massif, Korean Peninsula and its tectonic significance: Gondwana Research, v. 47, pp. 291-307.

Ramsay, J.G., and Huber, M.I., 1987, The Techniques of Modern Structural Geology. In: Folds and Fractures, v. 2. Academic press, London, $391 \mathrm{pp}$.

Rubatto, D., 2002, Zircon trace element geochemistry: partitioning with garnet and the link between $\mathrm{U}-\mathrm{Pb}$ ages and metamorphism. Chemical Geology, v. 184, pp. 123-138.

Sanderson, D. J., and Marchini, W.R.D., 1984, Transpression. Journal of Structural Geology, v. 6, pp. 449-58.

Seo, J., Choi, S.G., and Oh, C.W., 2010, Petrology, geochemistry, and geochronology of the Post-collisional Triassic mangerite and syenite in the Gwangcheon area, Hongseong Belt, South Korea. Gondwana Research, v. 18, pp. 479-496.

Sláma, J., Košler, J., Condon, D.J., Crowley, J.L., Gerdes, A., Hanchar, J.M., Horstwood, M.S.W., Morris, G.A., Nasdala, L., Norberg, N., Schaltegger, U., Schoene, B., Tubrett, M.N., and Whitehouse, M.J., 2008, Plešovice zircon- a new natural reference material for $\mathrm{U}-\mathrm{Pb}$ and $\mathrm{Hf}$ isotopic microanalysis. Chemical Geology, v. 249, pp. 1-35.

Tanner, P.W.G., 1989, The flexural-slip mechanism. Journal of Structural Geology, v. 11, pp. 635-655.

Thiessen, R., 1986, Two-dimensional refold interference patterns. Journal of Structural Geology, v. 8, pp. 563-573.

Vermeesch, P., 2018, IsoplotR: a free and open toolbox for geochronology. Geoscience Frontiers, v. 9, pp. 1497-1493.

Wiedenbeck, M., Allé, P., Corfu, F., Griffin, W.L., Meier, M., Oberli, F., von Quadt, A., Roddick, J.C., and Spiegel, W., 1995, Three natural zircon standards for $\mathrm{U}-\mathrm{Th}-\mathrm{Pb}, \mathrm{Lu}-\mathrm{Hf}$, trace element and REE analyses. Geostand Newslett, v. 19, pp. 1-23.

Woodcock, N.H., and Schubert, C., 1994, Continental strike-slip tectonics. In Continental Deformation (ed. P. L. Hancock), pp. 251-63. Pergamon Press. 


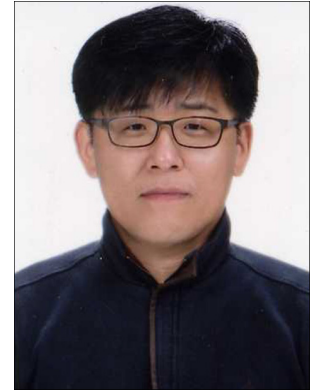

Hyeong Soo Kim is a professor of petrology in the Department of Earth and Environmental Sciences at Korea University, South Korea. He received a $\mathrm{PhD}$ in geology at James Cook University, Australia. His specialty is the field of interrelationship between deformation and metamorphism combined with P-T modeling of metamorphic mineral assemblages. His current research focuses on development of microstructures during the late Paleozoic regional metamorphism to understand tectonometamorphic evolution of East Asia during the late Paleozoic-early Mesozoic.

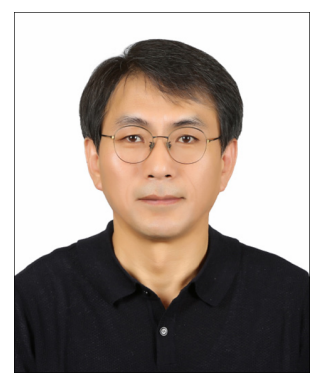

Hee-Cheol Kang is a senior researcher and lecturer in Department of Geological Sciences, Pusan National University, Busan, Korea. He received his Ph.D. from Pusan National University. His major research focuses on tectonics, structural geology and geophysical survey. He recently published papers on pseudotachylytes, a product of brittle deformation. He participates in the research of national active faults and serves as an expert committee member for the National Geoparks of Korea.

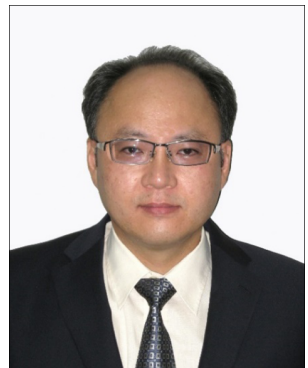

Hyoun Soo Lim is an associate professor of sedimentary geology in Department of Geological Sciences, Pusan National University, Busan, Korea. He received his Ph.D. from Seoul National University, Korea. His main research focuses on the low-temperature thermochronology, Quaternary geology, paleoclimate, geoarcheology and polar science. He won the Young Geologist Award (2008) and Academic Award (2019) from the Geological Society of Korea, and the Challenge Award (2009) from the Korea Polar Research Institute. He has served as an editorial board member for the Geosciences Journal and Korean Journal of Quaternary Research.

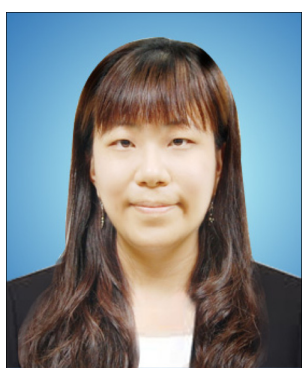

Shinae Lee is a researcher and in charge of SHRIMP (Sensitive High Resolution Ion Microprobe) laboratory at Division of Center for Research Equipment, Korea Basic Science Institute (KBSI). She received her B.Sc. (2005), M.Sc. (2013) degrees from the Chungnam National University in Daejeon, Republic of Korea. Her research interests include environmental geochemistry and studies of mineral $\mathrm{U}-\mathrm{Pb}$ age dating using SHRIMP. 